\title{
Volatile and Flavonoid Composition of the Peel of Citrus medica L. var. Corsican Fruit for Quality Assessment of Its Liqueur
}

\author{
Nicolas Venturini ${ }^{1}$, Toussaint Barboni ${ }^{1}$, Franck Curk ${ }^{2}$, Jean Costa ${ }^{1}$ and Julien Paolini ${ }^{1 *}$ \\ ${ }^{1}$ University of Corsica, CNRS-UMR 6134, Laboratory of Natural Product Chemistry, BP 52, \\ FR-20250 Corte, France \\ ${ }^{2}$ UR-INRA GEQA 110, Center INRA of Corsica, FR-20230 San Ghjulianu, France \\ Received: May 7, 2014 \\ Accepted: October 6, 2014
}

\begin{abstract}
Summary
The volatile and flavonoid compositions of the peel of Citrus medica L. var. Corsican fruits cultivated in Corsica were studied according to the maturity of the citron fruits measured using growing degree-days. Quantitative variation with the stage of development of the fruit was observed using gas chromatography, gas chromatography-mass spectrometry, and liquid chromatography-mass spectrometry/mass spectrometry. Thirty volatile compounds were identified in the peel essential oil. Limonene and $\gamma$-terpinene were the major compounds. The volatile compositions of commercial citron liqueurs were also characterized by high amounts of monoterpene hydrocarbons with the same two major components. The main flavonoid components of citron fruits and derived liqueurs were rutin and neohesperidin. This chemical characterization can be used for quality assessment of food products from C. medica var. Corsican.
\end{abstract}

Key words: Citrus medica L. var. Corsican, citrus peel, flavonoid compounds, essential oil, commercial citron liqueur

\section{Introduction}

Citrus fruits have an important role in the world economy, and in local regions of the Mediterranean area, such as Corsica, they are consumed either directly or processed. The citron (Citrus medica L.) belongs to the family Rutaceae, subfamily Aurantiaca, tribe Citrae (1). Systematic studies highlight the major role of citron in the phylogeny of several varieties of the Citrus genus as the pollinator parent (2-6). All taxonomists recognize the contribution of the citron to the development of several important cultivated genotypes. For instance, citron combined with sour orange (C. aurantium) and C. micrantha is phylogenetically the ancestor of lemon (C. limon) and lime (C. aurantifolia), respectively $(7,8)$. Citron trees are small, 3 to $5 \mathrm{~m}$ high, with thorny branches and oval, elongated leathery leaves. Considered indigenous to northeastern India, Myanmar, and Yunnan province of China, the citron was the first Citrus species introduced to the Mediterranean basin.

During the 1890s, Corsica was the world's leading citron producer, exporting 1700 tonnes of fruit per year. The brined fruits were shipped mainly to northern Europe and used as candied peel in traditional Christmas cakes. In Corsica, only 5 or 6 ha of citron were still cultivated in 2008; the variety grown is Corsican. The flowers of this variety are white, while those of other citron varieties are usually purple or pink. The Corsican variety is the only one of the citron group that has acid-free pulp (juice vesicles) and sweet albedo. The fruit of the Corsican variety is generally light orange-yellow to cadmium yellow, large and elliptical in shape, $7-10 \mathrm{~cm}$ i.d., $8-14 \mathrm{~cm}$ in length, with a rind about $3-4 \mathrm{~cm}$ thick. The citron's highly scented peel is attributed to its external vesicles, which contain es- 
sential oils, rather than its pulp, which is seldom consumed. Its skin is thick, and its white inner tissue, called albedo, is consumed usually after being processed into jam or candied fruit. In Corsica, the main product from the peel is a local liqueur (called Cédratine in French or Aliméa in Corsican language). For the production of this alcoholic beverage, the harvest of citron fruits runs usually from September to November. A second set of fruits can be also collected from January to February.

Several chemical studies have reported the volatile composition of peel from C. medica. The peel essential oil composition from various citron varieties has also been investigated: Etrog, Diamante, Rhobs el Arsa, Buddha's hand and Corsican (9-14). These studies showed quantitative differences with regard to the major constituents: limonene, $\gamma$-terpinene, geranial and neral. Thus, several chemical compositions of the same variety have been reported according to their geographical origins. Venturini et al. (15) reported the chemical compositions of peel and leaf oils from 17 citron cultivars. According to the levels of seven components (limonene, $\beta$-pinene, $\gamma$-terpinene, neral, geranial, nerol and geraniol), the citron cultivars were classified in four main oil chemotypes. To our knowledge, there have been no studies on the polyphenolic composition of C. medica var. Corsican. However, some articles have dealt with flavonoid components in other varieties of C. medica (16-18). The flavonoids reported in the fruits are rutin and hesperidin derivatives (sakuranetin, 7-O-methyl-aromadendrin, dihydrokaempferide). High amounts of glycosylated flavones, flavanones, and dihydrochalcone were also identified; the major compounds were $C$ - and/or $O$-glycosides of apigenin, phloretin, diosmetin and hesperetin.

As part of our investigations on the chemical characterization of citron varieties (15) and alcoholic beverages from Corsica (19), the aim of this work is to provide a better knowledge of the chemical characteristics (volatile and polyphenolic compositions) of typical commercial liqueurs from C. medica var. Corsican. This characterization should lead to a better valorization of these products by standardization of their quality.

\section{Materials and Methods}

\section{Sampling of plant material}

One thousand and five hundred fruits of Citrus medica var. Corsican (bourgeoning stage) were selected from 100 trees grown under the same pedoclimatic conditions. All trees were grown on a plantation at Vescovato, Corsica, France (latitude $42^{\circ} 29^{\prime} \mathrm{N}$, longitude $9^{\circ} 30^{\prime} \mathrm{E}$, Mediterranean climate, soil derived from alluvial deposits and classified as fersiallitic). Citron fruits were collected each month from July to January. Phenotypic characteristics of fruits such as mass, length, width, and colour were measured each month. These fruit samples were also used for the preparation of peel essential oil and solvent extracts at each harvest.

\section{Determination of fruit maturity}

The degree of maturity of Corsican citron was evaluated using the method described by Stenzel et al. (20) and based on the calculation of growing degree-days (GDD). It should be noted that this procedure provides results independent of interannual variations of temperature, but dependent on the species or varieties and environmental factors. The flowers of C. medica var. Corsican were scored at the date of anthesis (flowers blooming on April 15, 2010). From this date until the final harvest of the fruit (January $4,2011)$, the air temperature was measured daily by recorders placed on the canopy of three trees (facing east).

\section{Isolation of essential oil}

The peel of C. medica L. var. Corsican was water distilled $(5 \mathrm{~h})$ using a Clevenger-type apparatus (Midisciences, Fuveau, France) according to the method recommended in the European Pharmacopoeia and the essential oil yields were $0.40-0.72 \%$. Each distillation was performed in triplicate.

\section{Preparation of solvent extracts}

A mass of 100 grams of fresh peel was lyophilised and extracted at room temperature with ethanol $(1 \mathrm{~L})$. The solution was filtered on a Büchner funnel and extracted with ethyl acetate $(3 \times 100 \mathrm{~mL})$. The solution was evaporated, recovered in methanol $(50 \mathrm{~mL})$ and filtered through a 0.45 $-\mu \mathrm{m}$ membrane (Phenomenex, Le Pecq, France). Each polyphenol extraction was performed in triplicate.

\section{Essential oil analysis}

Gas chromatographic analysis was carried out using a Perkin-Elmer (Waltham, MA, USA) Autosystem XL apparatus equipped with dual flame ionization detection (FID) systems and two fused silica capillary columns $(60 \mathrm{~m} \times 0.22$ mm i.d.; film thickness $0.25 \mu \mathrm{m}$ ) coated with Rtx-1 (polydimethylsiloxane) and Rtx-Wax (polyethylene glycol). The oven temperature was programmed from 60 to $230{ }^{\circ} \mathrm{C}$ at 2 ${ }^{\circ} \mathrm{C} / \mathrm{min}$ and then held isothermally at $230{ }^{\circ} \mathrm{C}$ for $35 \mathrm{~min}$. The injector and detector temperatures were maintained at $280{ }^{\circ} \mathrm{C}$. Samples were injected in the split mode $(1 / 50)$ using helium as carrier gas $(1 \mathrm{~mL} / \mathrm{min})$; injection volume of pure oil was $0.2 \mu \mathrm{L}$. For headspace sampling by solid-phase microextraction and gas chromatography (HS-SPME-GC) analysis, only the Rtx-1 column was used and volatile components were desorbed in a GC injector with an SPME Intel liner (0.75 mm i.d.; Supelco, Bellefonte, PA, USA). Samples were also analyzed with a Perkin-Elmer Turbo mass detector (quadrupole), coupled to a Perkin-Elmer Autosystem XL, equipped with fused silica capillary columns Rtx- 1 and Rtx-Wax. Ion source temperature was $150{ }^{\circ} \mathrm{C}$, energy ionization was $70 \mathrm{eV}$, electron impact mass spectra were acquired over the mass range of 35-350 Da (scan time: $1 \mathrm{~s}$ ). Other GC conditions were the same as described above except for the use of a split ratio of $1 / 80$. For HS-SPME-GC-mass spectrometry (MS) analysis, only the Rtx-1 column was used and volatile components were desorbed in a GC injector with an SPME Intel liner $(0.75$ $\mathrm{mm}$ i.d.; Supelco). The identification of individual volatiles was based on comparison of calculated retention indices (apolar and polar columns) and mass spectra with those of our own library of authentic compounds or literature data $\left(I_{1}\right)(21)$. Retention indices $\left(I_{\mathrm{a}}\right.$ and $I_{\mathrm{p}}$, respectively) of the compounds were determined relative to the reten- 
tion times of series of $n$-alkanes $\left(\mathrm{C}_{5}-\mathrm{C}_{30}\right)$ with linear interpolation, using the Van den Dool and Kratz equation (22) and software from Perkin-Elmer. The relative concentrations of components were calculated based on the GC peak areas (apolar column Rtx-1) without using correction factors.

\section{Analysis of solvent extract}

Solvents and reagents used for sample preparation and chromatography were LC-MS grade acetonitrile (ACN) and ammonium acetate $\left(\mathrm{NH}_{4} \mathrm{OAc}\right.$, LC-MS grade) obtained from Fisher Scientific (Illkirch, France). Deionized water was purified using a MilliQ water (Millipore, Bedford, MA, USA) purification system. Reference flavonoids (99\% purity determined by high-performance liquid chromatography (HPLC) were purchased from Extrasynthese (Geney, France). Solutions of reference compounds were prepared by dissolving the compounds in $\mathrm{ACN}$ at $1 \mathrm{mg} / \mathrm{mL}$ and then filtered through a $0.2-\mu \mathrm{m}$ polytetrafluoroethylene (PTFE) filter. Direct-infusion MS analyses were performed with reference solutions at a concentration of $0.1 \mathrm{mg} / \mathrm{mL}$ in volume ratio of $\mathrm{ACN} /$ $\mathrm{H}_{2} \mathrm{O}=5: 5$ and $0.1 \% \mathrm{NH}_{4} \mathrm{OH}$. Prior to LC-MS/MS analysis, the mixture was diluted in the initial mobile phase to obtain the desired concentrations.

The LC system consisted of a Flexar ultra-high-performance liquid chromatography (UHPLC; Perkin-Elmer) with two Flexar FX-10 UHPLC pumps, a Flexar solvent manager, a 275-Flexar autosampler, and a Flexar LC PE200 column oven. UHPLC analyses were performed on a 100 $\mathrm{mm} \times 2.1 \mathrm{~mm}$ i.d., $3 \mu \mathrm{m}$, LUNA 3U C18 column (Phenomenex) and the column temperature was set at $30^{\circ} \mathrm{C}$. A volume of $10 \mu \mathrm{L}$ of sample was injected using an injection loop of $15 \mu \mathrm{L}$ in full loop mode. The mobile phase consisted of MilliQ water (solvent A) and ACN (solvent B) with $0.1 \%$ (by volume) $\mathrm{NH}_{4} \mathrm{AcO}$ acetate buffer at a flow rate of $500 \mu \mathrm{L} / \mathrm{min}$. The column was equilibrated in $90 \%$ $\mathrm{A}$ and $10 \% \mathrm{~B}$ for $5 \mathrm{~min}$, and elution was carried out with the following linear gradient from 90 to $10 \%$ A in 2 min, an increase from $10 \% \mathrm{~A}$ to $100 \%$ in $14 \mathrm{~min}$, and $100 \% \mathrm{~A}$ for $6 \mathrm{~min}$.

Mass spectra were acquired using an AB Sciex (Toronto, Canada) 3200 QTRAP linear triple quadrupole fitted with an electrospray ionization (ESI) source operating in positive or negative mode. High purity nitrogen was used as both nebulizer and turbo gas. The ESI source was operated with following settings in positive mode: curtain gas (CUR) 25 psi, nebulizer gas (GS1) 31 psi, heater gas (GS2) 65 psi, ion spray voltage (IS) $5000 \mathrm{~V}$ and temperature $550{ }^{\circ} \mathrm{C}$. The following settings were used in negative mode: CUR 25 psi, GS1 41 psi, GS2 65 psi, IS -4200 V and temperature $550{ }^{\circ} \mathrm{C}$. For enhanced product ion (EPI) experiments, the MS parameters were set as follows in positive ion mode: declustering potential (DP) $50 \mathrm{~V}$, entrance potential (EP) $10 \mathrm{~V}$, collision energy (CE) $-35 \mathrm{~V}$, and collision energy spread (CES) $\pm 15 \mathrm{~V}$, and in negative mode: DP $-80 \mathrm{~V}, \mathrm{EP}-10 \mathrm{~V}, \mathrm{CE}-35 \mathrm{~V}$, and CES $\pm 15 \mathrm{~V}$. The software used for data acquisition and data analysis was Analyst v. 1.5.1 (AB Sciex). For each reference compound, a relevant transition of the pseudomolecular ion was selected and the mass parameters were optimized in direct infusion (flow rate: $10 \mu \mathrm{L} / \mathrm{min}$ ) using the automated component optimization function of the Analyst software. Multiple EPI spectra were recorded in our MS spectral library for each compound. Data acquisition was performed in the multiple reaction monitoring (MRM) mode, followed by an EPI scan (MRM-EPI). EPI mass spectra were recorded in the range of $m / z=50-1000$ at $4000 \mathrm{Da} / \mathrm{s}$. Compound identification was allowed by comparison of retention time, MRM transition and the EPI mass spectrum of reference compounds. An external standard method was used for quantification of flavonoid compounds. The quantification was performed using a calibration curve obtained by serial diluted reference solution (six levels of concentrations with three injections per level) of each compound in our chromatographic conditions.

\section{Identification of flavonoid components}

The optimized MS/MS parameters (declustering potential, entrance potential, collision cell entrance potential, collission energy, collision cell, exit potential) and MRM transitions for each flavonoid component of $C$. medica var. Corsican extract were described in Table 1. According to the data previously reported in literature (23-26), the fragmentation mechanism of molecular ions to fragment ions used for MRM transitions was indicated in Table 1.

\section{Analysis of commercial liqueur}

Commercial citron liqueur prepared with C. medica var. Corsican peel (fruits harvested in November 2010) was provided by the Mavela distillery (Aleria, Corsica, France). These commercial liqueurs $(10 \mathrm{~mL}$ of sample in a $20-\mathrm{mL}$ vial) were subjected directly to HS-SPME. The SPME device (Supelco) coated with divinylbenzene/carboxen/polydimethylsiloxane (DVB/CAR/PDMS) (fibre $2 \mathrm{~cm}, 30 \mu \mathrm{m}$ thickness) was used for the extraction of volatile compounds from the liqueur. The extraction required the optimization of HS-SPME parameters (temperature and extraction times), based on the sum of total peak areas. The equilibrium time was $120 \mathrm{~min}$. The temperature and time of extraction were selected after three different experiments at 20,50 and $70{ }^{\circ} \mathrm{C}$, respectively, for each different extraction time $(15,30,60$ and $120 \mathrm{~min})$. The maximum sum of total peak areas was obtained at $20^{\circ} \mathrm{C}$ for $30 \mathrm{~min}$ for liqueurs. After sampling, the SPME fibre was inserted into the GC and GC-MS injection ports for desorption of volatile components $\left(5 \mathrm{~min}\right.$ at $\left.250^{\circ} \mathrm{C}\right)$, both using the splitless injection mode. Before sampling, each fibre was reconditioned for $5 \mathrm{~min}$ in the GC injection port at $260{ }^{\circ} \mathrm{C}$. HS-SPME and subsequent analyses were performed in triplicate. Volatile and flavonoid analyses of commercial citron liqueurs were performed using the same experimental parameters as those described for essential oil and solvent extractions, respectively.

\section{Results and Discussion}

\section{Fruit maturity according to growing degree-days}

Table 2 shows the number of days per month for which the formulae A, B and C described by Stenzel et al. (20) were applied, the GDD for each month (April to De- 
Table 1. MS/MS detection parameters of 13 flavonoid components of Citrus medica var. Corsican

\begin{tabular}{|c|c|c|c|c|c|c|c|c|c|c|}
\hline \multirow[b]{2}{*}{$\begin{array}{l}\text { Elution } \\
\text { order }\end{array}$} & \multirow[b]{2}{*}{ Compound } & \multirow[b]{2}{*}{ Type } & \multirow{2}{*}{$\frac{t}{\min }$} & \multicolumn{2}{|c|}{ Transition $/(m / z)^{*}$} & \multicolumn{5}{|c|}{ Optimized MS parameters } \\
\hline & & & & $\frac{\text { Q1 mass }}{\mathrm{Da}}$ & $\frac{\mathrm{Q} 3 \text { mass }}{\mathrm{Da}}$ & $\frac{\mathrm{DP}}{\mathrm{V}}$ & $\frac{E P}{V}$ & $\frac{\mathrm{CEP}}{\mathrm{V}}$ & $\frac{\mathrm{CE}}{\mathrm{V}}$ & $\frac{\mathrm{CXP}}{\mathrm{V}}$ \\
\hline 1 & Flavanomarein & $\begin{array}{l}\text { monoglycosylated } \\
\text { flavanone }\end{array}$ & 6.7 & 449.1 & 287.1 & -70 & -10 & -28 & -50 & -3 \\
\hline 2 & Hyperoside & $\begin{array}{l}\text { monoglycosylated } \\
\text { flavonol }\end{array}$ & 8.1 & 463.0 & 300.1 & -105 & -10 & -18 & -28 & -4 \\
\hline 3 & Narirutin & $\begin{array}{l}\text { diglycosylated } \\
\text { flavanone }\end{array}$ & 8.5 & 579.1 & 270.4 & -80 & -8.5 & -32 & -30 & -4 \\
\hline 4 & Diosmin & $\begin{array}{l}\text { diglycosylated } \\
\text { flavone }\end{array}$ & 7.5 & 607.1 & 299.1 & -80 & -10 & -34 & -35 & -3 \\
\hline 5 & Neohesperidin & $\begin{array}{l}\text { diglycosylated } \\
\text { flavanone }\end{array}$ & 7.5 & 609.1 & 301.1 & -80 & -10 & -34 & -35 & -3 \\
\hline 6 & Rutin & $\begin{array}{l}\text { diglycosylated } \\
\text { flavonol }\end{array}$ & 7.6 & 609.1 & 300.1 & -80 & -10 & -34 & -35 & -3 \\
\hline 7 & Retusin & $\begin{array}{l}\text { polymethoxylated } \\
\text { flavonol }\end{array}$ & 15.5 & 357.1 & 299.3 & -45 & -9 & -24 & -20 & -10 \\
\hline 8 & $\begin{array}{l}\text { Robinetin } \\
\text { trimethylether }\end{array}$ & $\begin{array}{l}\text { polymethoxylated } \\
\text { flavonol }\end{array}$ & 7.7 & 343.1 & 313.1 & -70 & -10 & -24 & -40 & -3 \\
\hline 9 & Luteolin & flavone & 9.9 & 287.0 & 153.1 & 20 & 10 & 17 & 35 & 6 \\
\hline 10 & Sinensetin & $\begin{array}{l}\text { polymethoxylated } \\
\text { flavonone }\end{array}$ & 9.7 & 373.1 & 343.3 & 71 & 4.5 & 30 & 27 & 6 \\
\hline 11 & Casticin & $\begin{array}{l}\text { polymethoxylated } \\
\text { flavonol }\end{array}$ & 10.1 & 375.1 & 359.1 & 50 & 10 & 20 & 35 & 3 \\
\hline 12 & Nobiletin & $\begin{array}{l}\text { polymethoxylated } \\
\text { flavone }\end{array}$ & 13.4 & 403.1 & 373.2 & 56 & 4.5 & 16 & 27 & 6 \\
\hline 13 & Tangeretin & $\begin{array}{l}\text { polymethoxylated } \\
\text { flavone }\end{array}$ & 14.3 & 373.1 & 343.3 & 81 & 8.5 & 28 & 25 & 14 \\
\hline
\end{tabular}

$\mathrm{DP}=$ declustering potential, $\mathrm{EP}=$ entrance potential, $\mathrm{CEP}=$ collision cell entrance potential, $\mathrm{CE}=$ collission energy, $\mathrm{CXP}=$ collision cell exit potential

${ }^{*} \mathrm{MRM}=\mathrm{Q} 1$ [molecular ions] and Q3 [fragment ions] Flavanomarein: Q1 [M-H]- $/ \mathrm{Q} 3\left[\mathrm{Yo}^{-}=\left[\mathrm{M}-\mathrm{C}_{6} \mathrm{H}_{11} \mathrm{O}_{5}\right]^{-}\right.$ Hyperoside: Q1 [M-H] $]^{-}$Q3 [Yo-H] $]^{-}=\left[\mathrm{M}-\mathrm{C}_{6} \mathrm{H}_{12} \mathrm{O}_{5}\right]^{-}$ Narirutin: Q1 [M-H] $]^{-} / \mathrm{Q} 3[\mathrm{YO}-\mathrm{H}]^{-\cdot}=\left[\mathrm{M}-\mathrm{C}_{12} \mathrm{H}_{22} \mathrm{O}_{9}\right]^{-}$ Diosmin: Q1 [M-H]- / Q3 [Yo] $]^{-}=\left[\mathrm{M}-\mathrm{C}_{12} \mathrm{H}_{21} \mathrm{O}_{9}\right]^{-}$ Neohesperidin: Q1 [M-H]- / Q3 [Yo $]^{-}=\left[\mathrm{M}-\mathrm{C}_{12} \mathrm{H}_{21} \mathrm{O}_{9}\right]^{-}$ Rutin: Q1 [M-H]- / Q3 [Yo-H $]^{-}=\left[\mathrm{M}-\mathrm{C}_{12} \mathrm{H}_{22} \mathrm{O}_{9}\right]^{-}$

cember), and the total GDD from the date of anthesis (April 15) to the harvest (July to January). The monthly GDD increased between April (68.2) and August (434.1), then decreased in the following months to reach 31.6 in December. The total GDD until the harvest date increased from June (705.0) until September (1927.7) and then took an asymptotic value (2105.5-2204.9) in the following months (October-December). Fruit maturity was obtained at a value of total GDD in the order of 2000. Stenzel et al. (20) showed that orange (C. aurantium) from Brazil requires 2500 to 3600 of total GDD to reach full maturity. This level of GDD does not seem to be necessary to obtain the maturity of the Corsican citron variety. This could be explained by the difference of climatic factors between Corsica (Mediterranean area) and Brazil (tropical area) or by the difference of metabolism between species (20).

The morphological characteristics (mass, length, and width) were measured at each harvest (Table 2), and they increased from July to October, after which they remained stable from October to January. Immature fruits had a dark
Retusin: Q1 [M-H] $]^{-}$Q3 [M-H-2 $\left.\mathrm{CH}_{3}-\mathrm{CO}\right]^{-}$

Robinetin trimethylether: Q1 $[\mathrm{M}-\mathrm{H}]^{-} / \mathrm{Q} 3\left[\mathrm{M}-\mathrm{H}-2 \mathrm{CH}_{3}\right]^{-}$

Luteolin: Q1 $[\mathrm{M}+\mathrm{H}]^{+} / \mathrm{Q} 3\left[{ }^{1,3} \mathrm{~A}\right]^{+}=\left[\mathrm{M}+\mathrm{H}-\mathrm{C}_{8} \mathrm{H}_{6} \mathrm{O}_{2}\right]^{+}$

Sinensetin: Q1 $[\mathrm{M}+\mathrm{H}]^{+} / \mathrm{Q} 3\left[\mathrm{M}+\mathrm{H}-2 \mathrm{CH}_{3}\right]^{+}$

Casticin: Q1 $[\mathrm{M}+\mathrm{H}]^{+} / \mathrm{Q} 3\left[\mathrm{M}-\mathrm{CH}_{3}\right]^{+}$

Nobiletin: Q1 $[\mathrm{M}+\mathrm{H}]^{+} / \mathrm{Q} 3\left[\mathrm{M}+\mathrm{H}-2 \mathrm{CH}_{3}\right]^{+}$

Tangeretin: Q1 $[\mathrm{M}+\mathrm{H}]^{+} / \mathrm{Q} 3\left[\mathrm{M}+\mathrm{H}-2 \mathrm{CH}_{3}\right]^{+}$

green colour (July-August), which changed to green-yellow (September-November) and to yellow (November-December) of mature fruits. After maturity, citron fruits take a yellow-orange colour. Corsican citron fruit is traditionally collected in November. The mature fruit (November) has a mass of $1100-1300 \mathrm{~g}$, length of $12-13 \mathrm{~cm}$, and width of $12.5-13.5 \mathrm{~cm}$.

\section{Analysis of volatile components}

The essential oil composition of the peel of C. medica var. Corsican according to the development stage of fruit was studied monthly from July to January (Table 3). Thirty compounds were identified in the peel essential oil (97.6-99.5\% of the total composition). Twelve monoterpene hydrocarbons, twelve oxygenated monoterpenes, four sesquiterpene hydrocarbons, and two linear oxygenated components were reported. Essential oil was dominated by monoterpene hydrocarbons (66.8-82.5\%). Limonene was the major compound (54.2-60.6\%) followed by 
Table 2. Growing degree-days (GDD) and phenotypic characteristics of C. medica var. Corsican according to fruit development

\begin{tabular}{lcccccccccc}
\hline & April & May & June & July & August & September & October & November & December & January \\
\hline Formula A & - & 15 & 25 & 17 & 27 & 24 & 14 & - & - & - \\
Formula B* & 15 & 14 & - & - & - & - & 17 & 30 & 31 & - \\
Formula C* & - & 2 & 5 & 14 & 4 & 6 & - & - & - & - \\
Monthly GDD & 68.2 & 300.1 & 336.7 & 444.9 & 434.1 & 343.7 & 177.8 & 67.8 & 31.6 & - \\
Total GDD & - & - & $\mathbf{7 0 5 . 0}$ & $\mathbf{1 1 4 9 . 9}$ & $\mathbf{1 5 8 4 . 0}$ & $\mathbf{1 9 2 7 . 7}$ & $\mathbf{2 1 0 5 . 5}$ & $\mathbf{2 1 7 3 . 3}$ & $\mathbf{2 2 0 4 . 9}$ & - \\
Mass/g & - & - & - & $119.1 \pm 33.5$ & $349.2 \pm 62.7$ & $821.4 \pm 201.1$ & $1218.6 \pm 187.1$ & $1122.6 \pm 272.2$ & $1203.0 \pm 146.3$ & $1289.1 \pm 281.7$ \\
Lenght/cm & - & - & - & $6.9 \pm 0.8$ & $9.3 \pm 1.0$ & $12.0 \pm 1.8$ & $12.4 \pm 1.5$ & $13.0 \pm 1.0$ & $12.4 \pm 1.3$ & $12.2 \pm 1.1$ \\
Width/cm & - & - & - & $6.0 \pm 0.6$ & $9.1 \pm 0.7$ & $11.7 \pm 1.4$ & $13.5 \pm 1.1$ & $12.5 \pm 1.3$ & $13.3 \pm 0.5$ & $13.3 \pm 1.2$ \\
Colour & - & - & - & dark green & dark green & green-yellow green-yellow & pale yellow & yellow & yellow-orange \\
\hline
\end{tabular}

*according to Stenzel et al. (21)

$\gamma$-terpinene (6.7-15.2\%). The oxygenated monoterpenes nerol, neral, geraniol and geranial were present in relatively high concentrations (2.9-8.2, 2.1-6.6, 1.8-5.9, and $2.1-5.7 \%$, respectively). These results are in accordance with those of Lota et al. (13) and Venturini et al. (15). Indeed, these authors have reported a chemotype limonene/ $\gamma$-terpinene of the Corsican citron variety. This combination had previously been observed in various Citrus species including limes (C. latifolia and C. aurantifolia), tangerine $(C$. reticulata $\times$ C. sinensis), mandarin (C. reticulata Blanco) and lemon (C. limon) (27-29).

During fruit development, the yield and the chromatographic profile of essential oil exhibited significant differences between immature fruits (July) and later harvested fruits (August to January). Fruit samples from July had an oil yield of $0.4 \%$, while the other samples exhibited yields near $0.7 \%$. The peel essential oil of $C$. medica var. Corsican showed a relatively stable chemical composition (Table 3) from August to January with a chromatographic profile dominated by limonene (57.8-54.6\%) and $\gamma$-terpinene (11.5-15.2\%). The content of the major component, limonene, can be considered stable (54.2\% in July, $54.6 \%$ in January). A significant difference between immature and mature fruits was only observed in the content of $\gamma$-terpinene. Relative percentages of $\gamma$-terpinene increased between July and the following months, whereas the content of nerol, neral, geraniol and geranial decreased in the same period. However, the decrease of nerol (5.9\% in July to $4.3 \%$ in November) and neral (from $5.7 \%$ in July to 4.7 $\%$ in January) is not related to fruit development (Table 3 ).

The HS-SPME volatile fraction of the commercial liqueur had seventeen components. All these compounds were also reported in Corsican citron essential oil. From a quantitative point of view, the volatile composition of citron peel oil and commercial liqueur showed several similarities, except for the essential oil from immature fruits (July). For instance, the major components were always limonene $(60.5 \%)$ and $\gamma$-terpinene $(21.8 \%)$. However, it was not possible to establish direct correlation between the chemical composition of the peel essential oil and that of the volatile fraction of liqueur obtained by HS-SPME. The two extraction processes (hydrodistillation vs. headspace) and HS-SPME parameters (particularly the temperature) could be responsible for the difference in the contents of oxygenated compounds.

\section{Analysis of flavonoid compounds}

As far as we know, the flavonoid composition of $C$. medica var. Corsican species has not been reported previously. Thirteen compounds were identified including three glycosylated flavanones, two glycosylated flavonols, one glycosylated flavone, one aglycone flavone, three polymethoxylated flavonols and three polymethoxylated flavones (Table 4). The main chemical classes determined on dry mass basis were the glycosylated flavonols (10.0-14.3 $\mathrm{mg} / \mathrm{g}$ ) followed by glycosylated flavanones (1.1-10.2 $\mathrm{mg} / \mathrm{g}$ ) and flavones $(0.5-9.9 \mathrm{mg} / \mathrm{g})$.

The main components were identified as rutin, diosmin, and neohesperidin. Mass fractions of flavonoids changed differently with fruit maturity. The rutin mass fraction was stable from July to January between 8.0 and $11.2 \mathrm{mg} / \mathrm{g}$. The mass fraction of diosmin decreased gradually from July to January (9.9 to $0.5 \mathrm{mg} / \mathrm{g}$, respectively). Conversely, the mass fraction of neohesperidin increased during fruit development from 0 (July) to $8.7 \mathrm{mg} / \mathrm{g}$ (January). The total concentration of flavonoids decreased from July to September (total GDD <2000) changing from 26.5 to $13.8 \mathrm{mg} / \mathrm{g}$ and then increased in the following months (October-January, total GDD >2000), reaching values between 18.6 and $25.3 \mathrm{mg} / \mathrm{g}$. From this result, it can be seen that the content of polyphenolic compounds varied during fruit development. Secondary metabolites may play a role in plant protection against photooxidative stress, in mediating thermotolerance and in direct defense against microbes and insects (30-32).

All polyphenolic compounds detected in the peel extract were also reported in the commercial liqueur. The major flavonoid compounds of this product were rutin $(16.8 \mathrm{mg} / \mathrm{g})$ and neohesperidin $(4.5 \mathrm{mg} / \mathrm{g})$. Rutin and hesperidin were also reported as major compounds of solvent extract from C. medica var. Etrog (18). To the best of our knowledge, C. medica is the only Citrus species containing these as main components. Two main types of glycosylated flavanones, neohesperidosides and rutinosides, had previously been reported in the peel compositions of other Citrus species (33). These two forms were identified in C. medica extract with neohesperidin and rutin as major components. However, the flavonoid composition of Corsican citron is quite different from that of other Citrus species. Bergamot, grapefruit, mandarin, lemon, and orange 


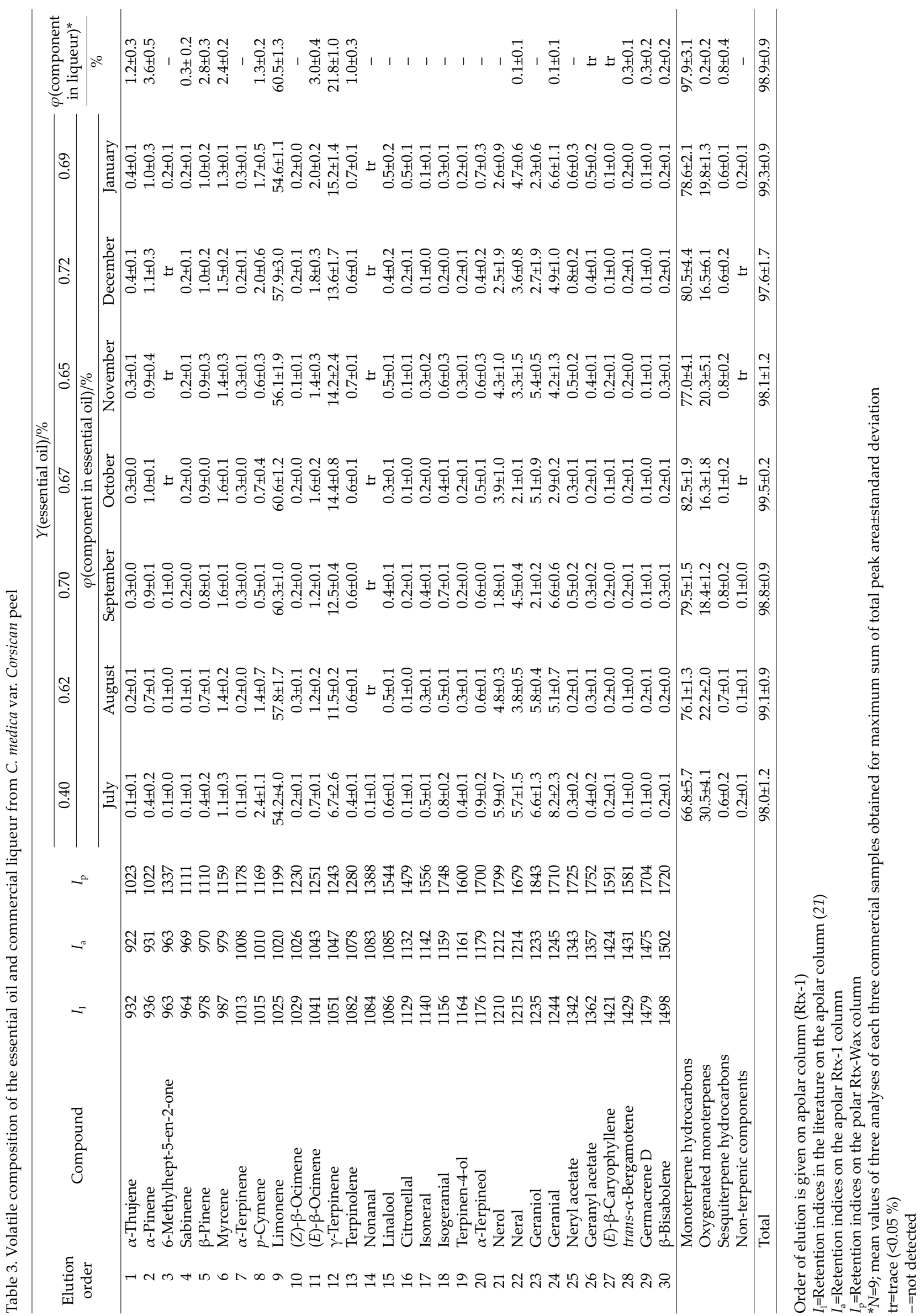


Table 4. Flavonoid composition of solvent extract and commercial liqueur on dry mass basis from C. medica var. Corsican peel

\begin{tabular}{|c|c|c|c|c|c|c|c|c|c|}
\hline \multirow{3}{*}{$\begin{array}{c}\text { Elution } \\
\text { order }\end{array}$} & \multirow{3}{*}{ Compound } & \multicolumn{7}{|c|}{ Solvent extract } & \multirow{3}{*}{ Liqueur } \\
\hline & & July & August & September & October & November & December & January & \\
\hline & & \multicolumn{7}{|c|}{$w($ flavonoid $) /(\mathrm{mg} / \mathrm{g})$} & \\
\hline 1 & Flavanomarein & $1.4 \pm 0.3$ & $1.3 \pm 0.3$ & $1.1 \pm 0.3$ & $0.9 \pm 0.3$ & $1.0 \pm 0.2$ & $1.3 \pm 0.3$ & $1.3 \pm 0.3$ & $1.1 \pm 0.3$ \\
\hline 2 & Hyperosid & $1.4 \pm 0.1$ & $1.4 \pm 0.1$ & $2.0 \pm 0.2$ & $2.2 \pm 0.5$ & $2.2 \pm 0.5$ & $3.1 \pm 0.4$ & $3.1 \pm 0.2$ & $3.2 \pm 0.8$ \\
\hline 3 & Narirutin & $0.1 \pm 0.1$ & $\operatorname{tr}$ & $0.1 \pm 0.0$ & $0.1 \pm 0.0$ & $0.1 \pm 0.0$ & $0.1 \pm 0.1$ & $0.1 \pm 0.1$ & $\operatorname{tr}$ \\
\hline 4 & Diosmin & $9.9 \pm 1.2$ & $6.1 \pm 1.1$ & $2.1 \pm 0.4$ & $1.0 \pm 0.3$ & $0.8 \pm 0.3$ & $0.7 \pm 0.2$ & $0.5 \pm 0.2$ & $0.4 \pm 0.1$ \\
\hline 5 & Neohesperidin & $1.2 \pm 0.1$ & $0.1 \pm 0.1$ & $\operatorname{tr}$ & $5.4 \pm 1.0$ & $6.9 \pm 0.8$ & $8.7 \pm 0.9$ & $8.7 \pm 0.6$ & $4.5 \pm 0.5$ \\
\hline 6 & Rutin & $10.4 \pm 0.9$ & $8.6 \pm 1.0$ & $8.0 \pm 0.5$ & $8.4 \pm 0.6$ & $9.0 \pm 1.0$ & $10.3 \pm 1.1$ & $11.2 \pm 1.0$ & $16.8 \pm 1.3$ \\
\hline 7 & Retusin & $\operatorname{tr}$ & $\operatorname{tr}$ & $\operatorname{tr}$ & $\operatorname{tr}$ & $\operatorname{tr}$ & $\operatorname{tr}$ & - & $\operatorname{tr}$ \\
\hline 8 & Robinetin trimethylether & $0.4 \pm 0.2$ & $0.2 \pm 0.0$ & $0.6 \pm 0.2$ & $0.4 \pm 0.2$ & $0.2 \pm 0.1$ & $0.5 \pm 0.1$ & $0.3 \pm 0.1$ & $0.3 \pm 0.2$ \\
\hline 9 & Luteolin & $0.1 \pm 0.0$ & $0.1 \pm 0.1$ & $\operatorname{tr}$ & $0.1 \pm 0.1$ & $0.1 \pm 0.0$ & $0.1 \pm 0.1$ & $\operatorname{tr}$ & $\operatorname{tr}$ \\
\hline 10 & Sinensetin & $\operatorname{tr}$ & - & $\operatorname{tr}$ & $\operatorname{tr}$ & $\operatorname{tr}$ & $\operatorname{tr}$ & $\operatorname{tr}$ & $\operatorname{tr}$ \\
\hline 11 & Casticine & $1.7 \pm 0.4$ & $0.3 \pm 0.1$ & $0.1 \pm 0.1$ & $0.1 \pm 0.1$ & $0.1 \pm 0.0$ & $0.2 \pm 0.1$ & $0.1 \pm 0.0$ & $\operatorname{tr}$ \\
\hline 12 & Nobiletin & $\operatorname{tr}$ & $\operatorname{tr}$ & $\operatorname{tr}$ & $\operatorname{tr}$ & $\operatorname{tr}$ & $\operatorname{tr}$ & $\operatorname{tr}$ & $\operatorname{tr}$ \\
\hline \multirow[t]{7}{*}{13} & Tangeretin & $\operatorname{tr}$ & $\operatorname{tr}$ & $\operatorname{tr}$ & $\operatorname{tr}$ & $\operatorname{tr}$ & - & - & $\operatorname{tr}$ \\
\hline & Polymethoxylated flavones & $0.1 \pm 0.1$ & $0.1 \pm 0.1$ & $\operatorname{tr}$ & $0.1 \pm 0.2$ & $0.1 \pm 0.1$ & $0.1 \pm 0.1$ & $\operatorname{tr}$ & $\operatorname{tr}$ \\
\hline & Flavones & $9.9 \pm 1.2$ & $6.1 \pm 1.1$ & $2.1 \pm 0.4$ & $1.0 \pm 0.3$ & $0.8 \pm 0.3$ & $0.7 \pm 0.2$ & $0.5 \pm 0.2$ & $0.4 \pm 0.2$ \\
\hline & Glycosylated flavanones & $2.7 \pm 0.5$ & $1.4 \pm 0.4$ & $1.1 \pm 0.3$ & $6.4 \pm 1.2$ & $7.9 \pm 1.0$ & $10.1 \pm 1.3$ & $10.2 \pm 0.8$ & $5.7 \pm 1.6$ \\
\hline & Polymethoxylated flavonols & $2.1 \pm 0.5$ & $0.5 \pm 0.1$ & $0.6 \pm 0.2$ & $0.5 \pm 0.2$ & $0.3 \pm 0.1$ & $0.7 \pm 0.1$ & $0.4 \pm 0.1$ & $0.3 \pm 0.2$ \\
\hline & Glycosylated flavonols & $11.8 \pm 0.9$ & $10.0 \pm 1.0$ & $10.0 \pm 0.7$ & $10.6 \pm 0.9$ & $11.2 \pm 1.4$ & $13.4 \pm 1.5$ & $14.3 \pm 1.2$ & $20.0 \pm 2.1$ \\
\hline & Total & $26.5 \pm 4.3$ & $18.0 \pm 3.2$ & $13.8 \pm 3.2$ & $18.6 \pm 3.9$ & $20.3 \pm 3.1$ & $25.0 \pm 3.9$ & $25.3 \pm 3.7$ & $26.4 \pm 3.2$ \\
\hline
\end{tabular}

Order of elution corresponds to that in Table 1

${ }^{*} N=9$, mean values of three analyses of three commercial samples \pm standard deviation tr=trace

juices are dominated by naringin, neohesperidin, and neoeriocitrin as neohesperidoside forms and by hesperidin, narirutin, and didymin as rutinoside forms (34).

\section{Conclusions}

Volatile fractions of Corsican citron liqueur were dominated by limonene and $\gamma$-terpinene in accordance with the essential oil composition of C. medica var. Corsican peel. High proportions of rutin and neohesperidin characterized the flavonoid fraction. The essential oil and polyphenolic composition of C. medica peel showed quantitative differences depending on fruit maturity. These results can be used for the quality assessment of organoleptic properties of food products (beverage, jam, nougat, and candy) derived from C. medica var. Corsican. Indeed, the commercial liqueur is traditionally made with mature fruits (harvested from September to November); however, the content of terpenic ( $\gamma$-terpinene) and polyphenolic (diosmin, neohesperidin, casticin) compounds varied substantially during fruit development.

\section{Acknowledgements}

The authors are indebted to the Territorial Collectivity of Corsica (CTC) and the Agency for the Economic Development of Corsica (ADEC) for partial financial support. The authors are also grateful to the Mavela distillery (Aleria, Corsica) for liqueur samples.

\section{References}

1. W. Swingle, P. Reece: The Botany of Citrus and Its Wild Relatives. In: The Citrus Industry, Vol. 1, W. Reuther, H.J. Webber, L.D. Batchelor (Eds.), University of California, Berkeley, CA, USA (1967) pp. 190-430.

2. S.N. Jena, S. Kumar, N.K. Nair, Molecular phylogeny in Indian Citrus L. (Rutaceae) inferred through PCR-RFLP and trnL-trnF sequence data of chloroplast DNA, Sci. Hortic. 119 (2009) 403-416. http://dx.doi.org/10.1016/j.scienta.2008.08.030

3. X. Li, R. Xie, Z. Lu, Z. Zhou, The origin of cultivated citrus as inferred from internal transcribed spacer and chloroplast DNA sequence and amplified fragment length polymorphism fingerprints, J. Am. Soc. Hort. Sci. 135 (2010) 341-350.

4. D.Q. Fang, M.L. Roose, Identification of closely related citrus cultivars with inter-simple sequence repeat markers, Theor. Appl. Genet. 95 (1997) 408-417. http://dx.doi.org/10.1007/s001220050577

5. E. Nicolosi, Z.N. Deng, A. Gentile, S. La Malfa, G. Continella, E. Tribulato, Citrus phylogeny and genetic origin of important species as investigated by molecular markers, Theor. Appl. Genet. 100 (2000) 1155-1166. http://dx.doi.org/10.1007/s001220051419

6. N.A. Barkley, M.L. Roose, R.R. Krueger, C.T. Federici, Assessing genetic diversity and population structure in a citrus germplasm collection utilizing simple sequence repeat markers (SSRs), Theor. Appl. Genet. 112 (2006) 1519-1531. http://dx.doi.org/10.1007/s00122-006-0255-9

7. A. Uzun, T. Yesiloglu, Y. Aka-Kacar, O. Tuzcu, O. Gulsen, Genetic diversity and relationships within Citrus and related 
genera based on sequence related amplified polymorphism markers (SRAPs), Sci. Hortic. 121 (2009) 306-312. http://dx.doi.org/10.1016/j.scienta.2009.02.018

8. F. Luro, N. Venturini, G. Costantino, J. Paolini, P. Ollitrault, J. Costa, Genetic and chemical diversity of citron (Citrus medica L.) based on nuclear and cytoplasmic markers and leaf essential oil composition, Phytochemistry, 77 (2012) 186-196. http://dx.doi.org/10.1016/j.phytochem.2011.12.013

9. Z. Fleisher, A. Fleisher, The essential oils of etrog (Citrus medica L. var. Ethrog Engl.), J. Essent. Oil Res. 3 (1991) 377-379. http://dx.doi.org/10.1080/10412905.1991.9697965

10. M. Poiana, V. Sicari, B. Mincioni, A comparison between the chemical composition of the oil, solvent extract and supercritical carbon dioxide extract of Citrus medica cv. Diamante, J. Essent. Oil Res. 10 (1998) 145-152. http://dx.doi.org/10.1080/10412905.1998.9700866

11. H. Shiota, Volatile components in the peel oil from fingered citron (Citrus medica L. var. sarcodactylis Swingle), Flavour Fragr. J. 5 (1990) 33-37.

http://dx.doi.org/10.1002/ffj.2730050106

12. S.A. Vekiari, E.E. Protopapadakis, N. Giannovits-Argyriadou, Composition of the leaf and peel oils of Citrus medica L. Diamante from Crete, J. Essent. Oil Res. 16 (2004) 528-530. http://dx.doi.org/10.1080/10412905.2004.9698789

13. M.L. Lota, D. De Rocca Serra, F. Tomi, J.M. Bessiere, J. Casanova, Chemical composition of peel and leaf essential oils of Citrus medica L. and C. limonimedica Lush, Flavour Fragr. J. 14 (1999) 161-166. http://dx.doi.org/10.1002/(SICI)1099-1026(199905/06)14:3<161: :AID-FFJ801>3.0.CO;2-8

14. B. Gabriele, A. Fazio, P. Dugo, R. Costa, L. Mondello, Essential oil composition of Citrus medica L. cv. Diamante (Diamante citron) determined after using different extraction methods, J. Sep. Sci. 32 (2009) 99-108. http://dx.doi.org/10.1002/jssc.200800404

15. N. Venturini, F. Curk, J.M. Desjobert, D. Karp, J. Costa, J. Paolini, Chemotaxonomic investigations of peel and petitgrain essential oils from 17 citron cultivars, Chem. Biodiv. 7 (2010) 736-751. http://dx.doi.org/10.1002/cbdv.200900028

16. K. Panara, K. Joshi, K. Nishteswar, A review on phytochemical and pharmacological properties of Citrus medica Linn, Int. J. Pharm. Biol. Arch. 3 (2012) 1292-1297.

17. S. Roowi, A. Crozier, Flavonoids in tropical citrus species, J. Agric. Food Chem. 59 (2011) 12217-12225. http://dx.doi.org/10.1021/jf203022f

18. M.H. Hetta, T.S. El Alfy, N.Z. Yassin, R.F. Abdel-Rahman, E.M. Kadry, Phytochemical and antihyperglycemic studies on Citrus medica L. leaves (Etrog) growing in Egypt, Int. J. Pharm. Phytochem. Res. 5 (2013) 271-277.

19. T. Barboni, N. Venturini, J. Paolini, J.M. Desjobert, N. Chiaramonti, J. Costa, Characterisation of volatiles and polyphenols for quality assessment of alcoholic beverages prepared from Corsican Myrtus communis berries, Food Chem. 122 (2010) 1304-1312. http://dx.doi.org/10.1016/j.foodchem.2010.03.087

20. N.M.C. Stenzel, C.S.V.J. Neves, C.J. Marur, M.B. Dos Santos Scholz, J.C. Gomes, Maturation curves and degree-days accumulation for fruits of 'Folha murcha' orange trees, Sci. Agric. 63 (2006) 219-225.

http://dx.doi.org/10.1590/S0103-90162006000300002
21. W.A. König, D. Joulain, D.H. Hochmuth, Terpenoids and Related Constituents of Essential oils, Library of Mass Finder 2.1, Institute of Organic Chemistry, Hamburg, Germany (2001).

22. H. Van Den Dool, P.D. Kratz, A generalization of the retention index system including linear temperature programmed gas-liquid partition chromatography, J. Chromatogr. A, 11 (1963) 463-471. http://dx.doi.org/10.1016/S0021-9673(01)80947-X

23. F. Cuyckens, M. Claeys, Mass spectrometry in the structural analysis of flavonoids, J. Mass Spectrom. 39 (2004) 1-15. http://dx.doi.org/10.1002/jms.585

24. N. Fabre, I. Rustan, E. de Hoffmann, J. Quetin-Leclercq, Determination of flavone, flavonol, and flavanone aglycones by negative ion liquid chromatography electrospray ion trap mass spectrometry, J. Am. Soc. Mass Spectrom. 12 (2001) 707-715. http://dx.doi.org/10.1016/S1044-0305(01)00226-4

25. V. Vukics, A. Guttman, Structural characterization of flavonoid glycosides by multi-stage mass spectrometry, Mass Spectrom. Rev. 29 (2010) 1-16.

26. K.W. Wang, H. Zhang, Positive electrospray ionization tandem mass spectrometry of polymethoxylated flavones, Rapid Comm. Mass Spectrom. 23 (2009) 2107-2111. http://dx.doi.org/10.1002/rcm.4115

27. T. Barboni, F. Luro, N. Chiaramonti, J.M. Desjobert, A. Muselli, J. Costa, Volatile composition of hybrids Citrus juices by headspace solid-phase micro extraction/gas chromatography/mass spectrometry, Food Chem. 116 (2009) 382-390. http://dx.doi.org/10.1016/j.foodchem.2009.02.031

28. M.L. Lota, D. de Rocca Serra, F. Tomi, J. Casanova, Chemical variability of peel and leaf essential oils of 15 species of mandarins, Biochem. Syst. Ecol. 29 (2001) 77-104. http://dx.doi.org/10.1016/S0305-1978(00)00029-6

29. M.L. Lota, D. de Rocca Serra, F. Tomi, C. Jacquemond, J. Casanova, Volatile components of peel and leaf oils of lemon and lime species, J. Agric. Food Chem. 50 (2002) 796-805. http://dx.doi.org/10.1021/jf010924l

30. S.C. Grace, B.A. Logan, Energy dissipation and radical scavenging by the plant phenylpropanoid pathway, Phil. Trans. R. Soc. Lond. 355 (2000) 1499-1510. http://dx.doi.org/10.1098/rstb.2000.0710

31. J. Diaz, A. Bernal, F. Pomar, F. Merino, Induction of shikimate dehydrogenase and peroxidase in pepper (Capsicum annum L.) seedlings in response to copper stress and its relation to lignification, Plant Sci. 161 (2001) 179-188. http://dx.doi.org/10.1016/S0168-9452(01)00410-1

32. A. Lavola, R. Julkunen Tiitto, T.M. de la Rosa, T. Lehto. P.J. Aphalo, Allocation of carbon to growth and secondary metabolites in birch seedlings under UV-B radiation and $\mathrm{CO} 2$ exposure, Physiol. Plant. 109 (2000) 260-267. http://dx.doi.org/10.1034/j.1399-3054.2000.100306.x

33. J. Macheix, A. Fleuriet, J. Billot: Fruit Phenolics, CRC Press, Boca Raton, FL, USA (1990).

34. E. Tripoli, M. La Guardia, S. Giammanco, D. Di Majo, M. Giammanco, Citrus flavonoids: Molecular structure, biological activity and nutritional properties: A review, Food Chem. 104 (2007) 466-479. http://dx.doi.org/10.1016/j.foodchem.2006.11.054\ 